\title{
Poliovirus Receptor Staining Finding
}

National Cancer Institute

\section{Source}

National Cancer Institute. Poliovirus Receptor Staining Finding. NCI Thesaurus. Code C131115.

The results of staining for poliovirus receptor in a sample. 